\title{
Platelet dysfunction in hypercholesterolemia mice, two Alzheimer's disease mouse models and in human patients with Alzheimer's disease
}

\author{
Barbara Plagg • Josef Marksteiner • \\ Kathrin M. Kniewallner • Christian Humpel
}

Received: 3 March 2015/Accepted: 28 April 2015/Published online: 7 May 2015

(C) The Author(s) 2015. This article is published with open access at Springerlink.com

\begin{abstract}
Alzheimer's disease (AD) is a severe neurodegenerative disorder characterized mainly by accumulation of amyloid- $\beta$ plaques and neurofibrillary tangles, synaptic and neuronal loss. Blood platelets contain the neurotransmitter serotonin and amyloid-precursor protein (APP), and may thus be useful as a peripheral biomarker for AD. The aim of the present study was to functionally characterize platelets by FACS, to examine alterations in APP expression and secretion, and to measure serotonin levels in hypercholesterolemia mice with AD-like pathology and in two AD mouse models, the triple transgenic $\mathrm{AD}$ model $(3 \mathrm{xTg})$ and the APP overexpressing AD model with the Swedish-Dutch-Iowa mutations (APP_SweDI). These data are supplemented with epidermal growth factor (EGF) levels and compared with changes observed in platelets of patients with $\mathrm{AD}$. We observed decreased platelet APP isoforms in $3 \times \mathrm{Tg}$ mice and patients with $\mathrm{AD}$ when analysed by means of Western blot. In patients, a significant increase of APP levels was observed when
\end{abstract}

B. Plagg · K. M. Kniewallner · C. Humpel $(\bowtie)$ Laboratory of Psychiatry and Experimental Alzheimer's Research, Department of Psychiatry and Psychotherapy, Medical University of Innsbruck, Anichstr. 35, 6020 Innsbruck, Austria

e-mail: christian.humpel@i-med.ac.at

J. Marksteiner

Department of Psychiatry and Psychotherapy A,

Landeskrankenhaus Hall, Hall in Tirol, Austria assessed by ELISA. Secreted APP $\beta$ proved to be altered amongst all three animal models of $\mathrm{AD}$ at different time points and in human patients with AD. Serotonin levels were only reduced in 7 and 14 month old 3xTg mice. Moreover, we found significantly lower EGF levels in human AD patients and could thereby reproduce previous findings. Taken together, our data confirm that platelets are dysfunctional in $\mathrm{AD}$, however, results from $\mathrm{AD}$ animal models do not coincide in all aspects, and markedly differ when compared to AD patients. We support previous data that APP, as well as EGF, could become putative biomarkers for diagnosing $\mathrm{AD}$ in human platelets.

Keywords Alzheimer's disease - Platelets .

Biomarker · Amyloid-precursor protein .

Epidermal growth factor $\cdot$ Serotonin

\section{Introduction}

Alzheimer's disease (AD) is a progressive neurodegenerative disease that gradually leads to severe cognitive deterioration and premature death. The main neuropathological hallmarks of $\mathrm{AD}$ concurrently include accumulation of amyloid- $\beta$ (A $\beta$ ) plaques, neurofibrillary tangles (NFT), inflammation and glial responses, synaptic and neuronal loss and vascular alterations. In addition, reduced acetylcholine concentrations as well as a severe decrease of monoamine 
transmitters serotonin, dopamine and norepinephrine are observed in patients with AD (Trillo et al. 2013).

$\mathrm{AD}$ is classified into clinically indistinguishable early-onset familiar AD (EOAD) and late-onset sporadic $\mathrm{AD}$ (LOAD). While EOAD accounts for approximately $1-5 \%$ of all cases and is associated with autosomal dominantly inherited mutations with a high penetrance, LOAD accounts for $>95 \%$ of all AD cases and turned out to be a complex heterogeneous disease. Effectively, the diagnosis of possible or probable $\mathrm{AD}$ requires according to the current $\mathrm{Na}-$ tional Institute of Neurological and Communicative Disorders and Stroke and the $\mathrm{AD}$ and Related Disorders Association (NINCDS-ADRDA) criteria both the presence of cognitive impairment established by clinical and neuropsychological examination and the absence of other diseases capable of producing a dementia syndrome, while definite AD diagnosis still requires post-mortem evaluation of plaques and NFTs in brain tissue (McKhann et al. 1984; Dubois et al. 2007). Thus, the diagnosis of AD within the clinical routine is based on a time consuming combination of psychological testing, imaging and the analysis of three well-established biomarkers (amyloid- $\beta_{42}$ $\left(\mathrm{A} \beta_{42}\right)$, total tau and phospho-tau-181) in cerebrospinal fluid (CSF) (Blennow 2005; Blennow et al. 2010; Zetterberg et al. 2010; Tapiola et al. 2009; Dubois et al. 2007). The increasing rate of $A D$ cases not only stresses the establishment of efficient therapeutic intervention, but also the identification of economic and reliable biomarkers in blood, urine, or saliva since CSF collection is an invasive procedure and an expensive analysis (Humpel 2011). We and others extensively searched for biomarkers in plasma/ serum (Blennow et al. 2010; Ray et al. 2007; Song et al. 2009; Hu et al. 2012; Chiu et al. 2013), peripheral blood mononuclear cells (Hu et al. 2014; Kassner et al. 2008), monocytes (Hochstrasser et al. 2012a; Naert and Rivest 2013; Shad et al. 2013; Bradshaw et al. 2013) or platelets (Adolfsson et al. 1980; Di Luca et al. 1996; Borroni et al. 2010; Casoli et al. 2010; Marksteiner and Humpel 2013).

Platelets can be considered a valid peripheral model to study metabolic mechanisms related to AD: these anuclear blood cells share several biochemical and homeostatic functions with neural cells such as accumulation and release of neurotransmitters like serotonin, glutamate and dopamine, and expression of membrane-bound components as receptors and enzymes (El Haouari and Rosado 2009). Also, human platelets are known to be the most important source for more than $90 \%$ of the circulating APP (Li et al. 1994; Padovani et al. 2001) and store $A \beta$ (especially $\left.A \beta_{40}\right)$ in their granules, which is released upon stimulation by physiological agonists like thrombin, collagen or calcium ionophores (Li et al. 1999; Bush et al. 1990; Kokjohn et al. 2011; Skovronsky et al. 2001). Recently, also tau protein, the major component of NFTs seen in $\mathrm{AD}$, has been identified in platelet proteome (Neumann et al. 2011). Moreover, platelets are known to play an important role in a variety of cardiovascular, psychosomatic, psychiatric and neurodegenerative diseases. On these grounds, platelets have been a promising target within the search for peripheral biomarkers in AD.

Up to now, several studies have reported significantly lower platelet APP ratio (i.e. the ratio between the upper $130 \mathrm{kDa}$ and the lower $106-110 \mathrm{kDa}$ isoforms) in $\mathrm{AD}$ patients correlating positively with cognitive decline (Di Luca et al. 1996, 1998; Borroni et al. 2004; Tang et al. 2006; Zainaghi et al. 2012). Discrepant results regarding platelet serotonin concentration, processing and uptake have been published: increased and decreased, as well as unchanged serotonin metabolism were reported, precluding a final evaluation on platelet serotonin status in $\mathrm{AD}$ (Tukiainen et al. 1981; Andersson et al. 1991; Prokšelj et al. 2014; Mimica et al. 2008; Muck-Seler et al. 2009; Kumar et al. 1995; Koren et al. 1993; Arora et al. 1991). Decreased platelets EGF, as well as increased sAPP $\beta$ levels in patients with $\mathrm{AD}$ and $\mathrm{MCI}$ were previously reported by our group (Hochstrasser et al. 2012b; Marksteiner and Humpel 2013). Other platelet components such as activation, membrane fluidity or enzymatic activity have been investigated in patients with $\mathrm{AD}$, inconsistent results have, however, to date impeded the establishment of a valid platelet-derived biomarker.

Mutant mouse models exhibiting traits such as plaque and tangle pathology, vascular aberrations and cognitive decline similar to those seen in AD have been widely used in AD research. However, transgenic AD mouse models represent more a familiar form of $\mathrm{AD}$ and reflect only partly the entire AD pathology. The APP_SweDI mouse model, harbouring the Swedish K670N/M671L and vasculotropic Dutch/ Iowa E693Q/D694N mutations, is a well-established model showing severe $A \beta$ plaque-like depositions 
starting at 6 months of age, cognitive decline and vascular pathology including cerebral amyloid angiopathy (CAA) but no tau pathology (Davis et al. 2004). The triple-transgenic model (3xTg) however, develops a neuropathological phenotype including besides synaptic dysfunction both $\mathrm{A} \beta$ plaques and tangle pathology at late stage (Oddo et al. 2003). Along with genetic interventions, weak traits of sporadic $\mathrm{AD}$ and visible cognitive decline are seen in different animals and AD mouse models with hypercholesterolemia (Sparks et al. 1994; Ullrich et al. 2010). While cholesterol diet triggers in wildtype control mice a weak decline in cognition most pronounced at 7 months, it elicits only very weak AD-like pathology (Hohsfield et al. 2014). Thus, the three mouse models may partly reflect AD pathology and are a useful tool to study AD-related processes. While recently platelet activation and thrombus formation in APP23 mice was investigated (Jarre et al. 2014), to the best of our knowledge platelet APP, sAPP $\beta$ and serotonin have not been studied in hypercholesterolemia and the two AD (APP_SweDI and $3 \times \mathrm{Tg}$ ) mouse models.

The aim of the present study is to extensively characterize AD-related alterations of platelet APP processing and secretion of $\mathrm{sAPP} \beta$, and to measure serotonin levels in three different mouse models: the hypercholesterolemia mouse model, the triple transgenic model displaying $A \beta$ plaques and tau pathology at late stage, and the APP_SweDI mouse model showing $A \beta$ plaques at an early stage, but no tau pathology. These data will be supplemented and compared with changes observed in platelets from patients with $\mathrm{AD}$.

\section{Materials and methods}

\section{Animals}

Wildtype (WT, 129/C57BL6 or C57BL/6N), tripletransgenic $\mathrm{AD}$ (3xTg-AD, B6; 129-Psen1 ${ }^{\text {tmlMpm- }}$ $\mathrm{Tg}$ (APPSwe, tauB301L)1Lfa/J) and transgenic APP_SweDI (Tg-SweDI; expressing amyloid precursor protein (APP) harboring the Swedish K670N/M671L, Dutch E693Q, and Iowa D694N mutations; C57BL/6Tg(Thy1-APPSwDutIowa) BWevn/Mmjax) mice were purchased from The Jackson Laboratory and housed at the Medical University of Innsbruck animal facility providing open access to food and water under 12/12 h light-dark cycles. All animals were genotyped according to standardized methods. At 2 months of age, wildtype mice began to receive either a normal diet or a well-established $5 \%$ cholesterol diet as described by us in detail (Ullrich et al. 2010; Hohsfield et al. 2014). The cholesterol containing nutrition was composed of: $450 \mathrm{~g} / \mathrm{kg}$ cornstarch, $140 \mathrm{~g} / \mathrm{kg}$ casein, $155 \mathrm{~g} / \mathrm{kg}$ maltodextrin, $100 \mathrm{~g} / \mathrm{kg}$ sucrose, $40 \mathrm{~g} / \mathrm{kg}$ soybean oil, $50 \mathrm{~g} / \mathrm{kg}$ fiber, $35 \mathrm{~g} / \mathrm{kg}$ mineral mix, $1.8 \mathrm{~g} / \mathrm{kg} \mathrm{L}$-cystine, $1.4 \mathrm{~g} / \mathrm{kg}$ choline chloride, $0.0008 \mathrm{~g} / \mathrm{kg}$ butylhydroxytoluol, $10 \mathrm{~g} / \mathrm{kg}$ vitamin mix (without folic acid), $1 \mathrm{~g} / \mathrm{kg}$ chocolate aroma, $0.002 \mathrm{~g} / \mathrm{kg}$ folic acid and $50 \mathrm{~g} / \mathrm{kg}$ cholesterol for animals on the cholesterol diet (ssniff special diet, Soest, Germany). All animal experiments were approved by the Austrian Ministry of Science and Research (BMWF-66.011/0044-II/3b/ 2011 and BMWF-66.011/0059-II/3b/2011) and conformed to the Austrian guidelines on animal welfare and experimentation. All possible steps were taken to reduce suffering and the number of animals used during the experiment.

\section{Patients}

Cognitively healthy subjects and patients suffering from $\mathrm{AD}$ were recruited at the Landeskrankenhaus Hall/Tirol, Austria. Thirty healthy persons (10 men and 20 women, aged $77 \pm 1$ years) and 43 patients with $\mathrm{AD}$ (18 men and 25 women, aged $80 \pm 1$ years) were included in this study. Both groups were assessed by the same diagnostic procedure. Diagnosis of $\mathrm{AD}$ was established by a structured routine process including clinical assessment, extensive neuropsychological tests (including mini-mental state examination, MMSE) and neuroimaging (magnetic resonance imaging, MRI) to exclude other brain pathologies. Probable AD was diagnosed according to the current NINCDSARDRA criteria and confirmed for all participating patients. A general blood examination was part of the routine diagnostic procedure. Exclusion criteria for healthy subjects, MCI and AD patients included (1) another primary neurological or mental disorder, (2) any kind of metabolic decompensation or any sign of peripheral inflammation (e.g. rheumatic disease), (3) long-term alcohol or drug abuse, (4) or any current, clinically significant cardiovascular disease. The study was approved by the ethics committee of Medical University of Innsbruck. All subjects and/or their 
caregivers enrolled in the study gave their informed consent.

Isolation of mouse platelets and processing

Mouse platelets were isolated as reported previously (Marksteiner and Humpel 2013). Briefly, mice were anaesthetized by an intraperitoneal injection of sodium thiopental $(12.5 \mathrm{mg} / \mathrm{ml}, 1 \mathrm{ml}$; Sandoz, Kundl, Austria). Blood drawn directly from the heart was immediately collected in ethylenediaminetetraacetate (EDTA) tubes (S-monovettes, Sarstedt, Germany), gently mixed and instantly centrifuged at $100 \times g$ for $10 \mathrm{~min}$ in order to part platelet rich plasma (PRP). PRP (upper phase) was collected and prostaglandine 2 (PGI2, 500 nM, Sigma, Vienna, Austria) added according to the obtained quantity of PRP $(19 \mu \mathrm{l} / \mathrm{ml})$ to avoid platelet activation during processing. Next, PRP was partitioned into two portions and then centrifuged at $400 \times g$ for $10 \mathrm{~min}$ to isolate platelets. An aliquot was dissolved in Tyrode buffer $(136 \mathrm{mM}$ $\mathrm{NaCl}, 2.7 \mathrm{mM} \mathrm{KCl}, 12 \mathrm{mM} \mathrm{NaHCO} 3,0.42 \mathrm{mM}$ $\mathrm{NaH}_{2} \mathrm{PO}_{4}, 1 \mathrm{mM} \mathrm{MgSo} 4,5 \mathrm{mM}$ glucose, $\mathrm{pH}$ 6.5) and immediately analysed $(6 \mu \mathrm{l})$ by FACS. The rest was dissolved in $100 \mu \mathrm{l} 1 \times$ secretase buffer $(20 \mathrm{mM}$ sodium acetate, $0.2 \%$ Triton, $\mathrm{pH} 4.5$ ), sonicated with a Branson sonifier (10 strokes each $10 \mathrm{~s}$ on ice), then centrifuged at $16,000 \times g$ for $10 \mathrm{~min}$ and the supernatant was collected, total protein was measured using the Bradford protein assay and the rest was frozen at $-80^{\circ} \mathrm{C}$ until use.

Isolation of human platelets and processing

Human platelets were isolated as previously described (Marksteiner and Humpel 2013). In short, $10 \mathrm{ml}$ blood was collected in EDTA tubes during normal clinical routine, centrifuged at $250 \times \mathrm{g}$ for $10 \mathrm{~min}$ at $\mathrm{RT}$ to collect platelet-rich plasma (PRP). PRP was centrifuged for $10 \mathrm{~min}$ at RT $(2300 \times g)$ and the pellet was dissolved in $1 \mathrm{ml}$ Tyrode's buffer and PGI2 was added in order to inhibit platelet activation. Next, the dissolved pellet was partitioned into three portions with each $330 \mu \mathrm{l}$ and then centrifuged at $2300 \times g$ for $10 \mathrm{~min}$.

\section{Sample A-human}

The pellet was resuspended in $150 \mu$ l secretase buffer (20 mM sodiumacetate, $0.2 \%$ Triton, $\mathrm{pH} 4.5$ ), sonicated with a Branson sonifier (10 strokes each $10 \mathrm{~s}$ on ice), then centrifuged at $14,000 \times g$ for $10 \mathrm{~min}$ and total protein determined by Bradford assay. The rest was frozen at $-80{ }^{\circ} \mathrm{C}$ until use.

\section{Sample B-human}

The pellet was resuspended in $100 \mu \mathrm{l}$ phosphate buffered saline (PBS) with a protease inhibitor cocktail (Sigma), sonicated with a Branson sonifier (10 strokes each $10 \mathrm{~s}$ on ice, $125 \mathrm{~W} / \mathrm{cm}^{2}, 140 \mu \mathrm{m}$ amplitude, $100 \%$ ), and centrifuged at $14,000 \times g$ for $10 \mathrm{~min}$. The supernatant was collected, again the total protein determined and frozen at $-80{ }^{\circ} \mathrm{C}$.

\section{Sample C-human}

To the platelet pellet $100 \mu \mathrm{l}$ Tyrode's buffer was added and analysed by FACS. The rest was incubated with $2 \mathrm{mM} \mathrm{CaCl}_{2}$ at $37{ }^{\circ} \mathrm{C}$ for $60 \mathrm{~min}$. Afterwards, the platelets were centrifuged at $1900 \times g$ for $10 \mathrm{~min}$ and the supernatant was frozen at $-80{ }^{\circ} \mathrm{C}$, while the pellet was dissolved in $100 \mu \mathrm{l}$ of $0.4 \mathrm{~N} \mathrm{NaOH}\left(1 \mathrm{~h}, 45^{\circ} \mathrm{C}\right)$ and again analysed for total protein content.

\section{FACS analysis}

Immediately after isolation, $2 \mu \mathrm{l}$ mouse platelets were incubated with antibodies against IgG1-FITC (Milteny Biotec, Bergisch Gladbach, Germany, order no.: 130-098-847, 1:25) or CD62P-FITC (BD Biosciences, Heidelberg, Germany, Cat: 561923, 1:25). Human platelets were incubated with antibodies against FITC Mouse IgG1 (BD Biosciences, Cat: 555748, 1:25) or FITC Mouse Anti-Human CD62P (BD Biosciences, Cat: 555523, 1:25). Subsequently, $46 \mu \mathrm{l}$ of FACs buffer ( 2 mM EDTA, $0.5 \%$ FCS ad $100 \mathrm{ml}$ PBS, pH 7.1) was added and the samples incubated for $30 \mathrm{~min}$ at $4{ }^{\circ} \mathrm{C}$ in dark. To study apoptosis, $2 \mu \mathrm{l}$ of platelets were incubated with $5 \mu \mathrm{l}$ Annexin V-FITC (Milteny Biotec, Order no.: 130-097-928) in $100 \mu \mathrm{l}$ Annexin V Binding Buffer (Miltenyi Biotec, 20x Stock Solution) at RT for $30 \mathrm{~min}$ in dark. Immediately before analysis, $2 \mu \mathrm{l}$ of 7-AAD (Miltenyi Biotec) was added. All samples were centrifuged at $300 \mathrm{~g}$ for $10 \mathrm{~min}$ and the pellets were resuspended in $100 \mu \mathrm{l}$ of FACs flow (BD FACSFlow). FACs analysis was instantly performed with a BD FACScan. 
Serotonin analysis by HPLC

Platelet serotonin was measured by high-performance liquid chromotography (HPLC) as previously described in detail by us (Ullrich et al. 2010). Thus, $20 \mu \mathrm{l}$ thawed supernatants or extracts were injected on the HPLC column. As the mobile phase a mixture of $0.05 \mathrm{M}$ trichloric acid (Merck, Darmstadt, Germany), $0.26 \mathrm{mM}$ EDTA, $1.36 \mathrm{mM} \mathrm{NaCl}, 1.81 \mathrm{mM}$ heptanesulfonic acid and $15 \%$ acetonitrile in HPLC water was used. The components of the samples were separated on a reversed-phase C18 Nucleosil column (Bartelt, Graz, Austria) at a flow rate of $1 \mathrm{ml} / \mathrm{min}$. For the detection of serotonin an electrochemical detector Antec II was used. The amount of serotonin in the samples was calculated based on the peak height at the serotonin-specific retention time (7.8 $\mathrm{min})$.

Western blot analysis

In order to analyse the expression of platelet APP, Western blot analysis was performed. Five $\mu \mathrm{g}$ acidic platelet extracts (neutralized with $\mathrm{PBS}$ pH 9.5) were denatured $\left(10 \min 70{ }^{\circ} \mathrm{C}\right)$ and loaded onto $4-12 \%$ BisTris polyacrylamide gel (Invitrogen Life Tech, Darmstadt, Germany) and separated by electrophoresis for $60 \mathrm{~min}$ at $200 \mathrm{~V}$. Consecutively, samples were electrotransferred to nylon PVDF Immobilon-PSQ membranes (Millipore, Vienna, Austria) at $30 \mathrm{~V}$ for 90 min with $20 \%$ methanol transfer buffer (Invitrogen). Protein detection was performed with Western Breeze Chemiluminescent System (Invitrogen). Thus, membranes were blocked for 30 min with blocking solution at RT on the shaker, then incubated with the primary antibody (Anti-Amyloid beta precursor protein antibody [Y188], abcam, Cambridge, UK, ab32136) overnight at $4{ }^{\circ} \mathrm{C}$. Following, blots were washed and incubated with antirabbit antibodies for $30 \mathrm{~min}$ at RT, again washed and incubated with CDP-Star chemiluminescent substrate solution (Invitrogen). Imaging was performed with a cooled CCD camera SearchLight camera. In order to quantify the protein amounts in each lane and ensure that there has been an even transfer from gel to membrane, a loading control with $\alpha$ Mouse IgG was performed.

\section{APP ELISA}

Platelet APP was measured using the APP ELISA (Invitrogen KHB0051, code 310314) kit according to the instruction manual. Briefly, $50 \mu \mathrm{l}$ of neutralized extracts were mixed with $50 \mu \mathrm{l}$ of standard diluent and $2 \mu \mathrm{l}$ of sample reducing agent (NuPage, Invitrogen) and denatured $\left(10 \mathrm{~min} 70{ }^{\circ} \mathrm{C}\right)$ and then put on ice. Next, $100 \mu \mathrm{l}$ of each sample/standard was added to the pre-coated wells, incubated overnight at $4{ }^{\circ} \mathrm{C}$, then washed, $100 \mu \mathrm{l}$ of biotinylated antibody was added and again incubated at RT for $1 \mathrm{~h}$. Afterwards, $100 \mu \mathrm{l}$ STREP-HRP was added, incubated at RT for $30 \mathrm{~min}$, washed, $100 \mu$ l of chromogen was added and incubated at RT in dark for $30 \mathrm{~min}$. Last, $100 \mu \mathrm{l}$ of stop solution was added and measured in the Zenyth ELISA reader (at $450 \mathrm{~nm}$ ). The APP values were calculated according to the standard curve.

\section{sAPP $\beta$ ELISA}

Secreted APP $\beta$ was analysed using the sAPP $\beta-w$ (highly sensitive) Assay Kit-IBL (code 27732, Immuno-Biological Laboratories, Hamburg, Germany) according to the manufacturer description. In brief, $12.5 \mu \mathrm{g}$ of the acidic platelet extracts were incubated in $50 \mu \mathrm{l}$ secretase buffer $(\mathrm{pH} 4.5)$ for $2.5 \mathrm{~h}$ at $37{ }^{\circ} \mathrm{C}$ in order to elicit the secretion process. Subsequently, $50 \mu$ of EIA buffer ( $1 \%$ BSA, $0.05 \%$ Tween 20 in PBS) was added and a total of $100 \mu \mathrm{l}$ for each sample/standard were incubated in the prepared wells overnight at $4{ }^{\circ} \mathrm{C}$, then washed, $100 \mu \mathrm{l}$ of labelled antibody was added, incubated for $30 \mathrm{~min}$ at $4{ }^{\circ} \mathrm{C}$, again washed, $100 \mu \mathrm{l}$ of chromogen was added and incubated at RT in dark for $30 \mathrm{~min}$. All incubation steps were carried out on a shaker. Successively, $100 \mu \mathrm{l}$ stop solution was added and the luminescent signal was detected with an ELISA reader Zenyth 3100 and the absorbance was measured at $450 \mathrm{~nm}$. The samples were calculated according to a standard curve.

\section{Human EGF ELISA}

Platelet EGF levels and EGF release after incubation were measured using human EGF ELISA kit (RayBiotech, ELH-EGF-001, THP Vienna, Austria). In short, PBS extracted samples $(5 \mu \mathrm{l})$ or supernatants $(30 \mu \mathrm{l})$ were added in $100 \mu \mathrm{l}$ diluent into pre-coated wells, covered and incubated for $2.5 \mathrm{~h}$ at RT with gentle shaking. Next, the solution was washed and $100 \mu \mathrm{l}$ of biotinylated antibody was added and again incubated for $1 \mathrm{~h}$ at RT. Afterwards, the solution was 
again discarded and washed and $100 \mu \mathrm{l}$ of Streptavidin solution was added. After 45 min the solution was discarded and washed and $100 \mu \mathrm{l}$ of TMP One-Step Substrate Reagent was added and incubated for $30 \mathrm{~min}$. Last, $50 \mu \mathrm{l}$ of Stop Solution was added and with an ELISA reader Zenyth 3100 the signal was detected $(450 \mathrm{~nm})$. The EGF values were calculated according to the standard curve.

Statistical analysis

Statistical analysis was performed by one Way ANOVA with a subsequent Fisher LSD posthoc test where $\mathrm{p}<0.05$ was significant.

\section{Results}

Wildtype control mice

Mouse platelets from wildtype mice (C57BL/6N) were isolated and characterized using FACS analysis, displaying a common population and marked CD62P expression (Fig. 1). Apoptotic and necrotic cell death was very low in young animals $(<0.5 \%)$ and slightly increased in older mice $(<9 \%)$. Serotonin levels were around $60 \mathrm{ng} / \mathrm{mg}$ protein and increased in older animals (Tables 1, 2, 3). APP like immunoreactivity was detectable in Western Blot as a single band at approximately $110 \mathrm{kDa}$ (Fig. 2), but did not markedly change during aging. APP as measured by ELISA was found to be approximately $2 \mathrm{ng} / \mathrm{mg}$ protein which increased in older animals (Table 3 ). The release of sAPP $\beta$ was approximately $3 \mathrm{ng} / \mathrm{ml} \times 12.5 \mu \mathrm{g} \times 150 \mathrm{~min}$ in WT mice.

\section{Hypercholesterolemia mouse model}

A cholesterol diet (5\%) for 7, 14 or 20 months did not significantly affect the platelet APP markers and serotonin (Table 1). Only a tendency for decreased sAPP $\beta$ release was observed in 20 month old hypercholesterolemic mice (Table 1).

Triple transgenic AD mouse model

APP $110 \mathrm{kDa}$ as measured by Western Blot significantly decreased in 7 , and 14 months but not in 20 months old $3 \times$ Tg mice (Table 2; Fig. 2). A significant reduction of $\operatorname{sAPP} \beta$ was observed at 7
Fig. 1 Flow cytometry (FACS) analysis in mouse (a, c, e, g) and human $(\mathbf{b}, \mathbf{d}, \mathbf{f}, \mathbf{h})$ platelets shows a common population of cells in forward and sideward scatter $(\mathbf{a}, \mathbf{b})$ and markedly expressed CD62P in mouse (c, green) but less in human (d, green) platelets, compared to an IgG control (red). Apoptosis was assessed using Annexin IV staining (e, f), showing examples of no apoptosis in mice (e) or increased apoptosis in humans (f, arrow). Necrosis was measured using 7-amino actinomycin D (7-AAD) in a mouse example (g) or coexpressed in apoptotic human platelets (h). (Color figure online)

and 14 months and more pronounced in 20 months old mice (Table 2). In the $3 \times \mathrm{Tg}$ mice there was a significant reduction of serotonin levels at 7 months, which was less noticeable in 14 months old animals and remained stable at 20 months (Table 2).

APP_SweDI AD mouse model

In this AD mouse model platelets showed markedly enhanced apoptosis and necrosis as determined by FACS analysis (Table 3; Fig. 1). Also, significantly increased CD62P positive cells in 12 months old transgenic animals were seen (Table 3). APP $110 \mathrm{kDa}$ did not change at any timepoint compared to controls (Fig. 2). The release of sAPP $\beta$ was significantly reduced at 6 months, but not at 12 months (Table 3). Serotonin levels were not significantly changed at any point in time (Table 3).

\section{Human samples}

In the human cohort, 43 patients with $\mathrm{AD}$ and 30 agematched and cognitively healthy persons were included. As expected, the MMSE scores were significantly lower in the AD-group $(18 \pm 1)$ compared to healthy subjects $(29 \pm 0.3)$ (Table 4$)$. AD patients were significantly older $(80 \pm 1$ years $)$ compared to the healthy volunteers $(77 \pm 1$ years).

Platelets were efficiently isolated $(50 \pm 2 \%$ IgG1 positive cells in healthy controls and $56 \pm 3 \%$ in patients with AD; Table 4; Fig. 1). FACS analysis revealed a moderate staining for CD62P (30 \pm 3 for controls and $26 \pm 3 \%$ for $\mathrm{AD}$ patients) (Table 4; Fig. 1). Also, moderate necrosis and apoptosis as visualized by Annexin and 7AAD was observed (Table 4; Fig. 1).

A reduction in the optical density of the $130 \mathrm{kDa}$ isoform and a tendency towards a reduction of the $110 / 106 \mathrm{kDa}$ isoform was found in our present human 

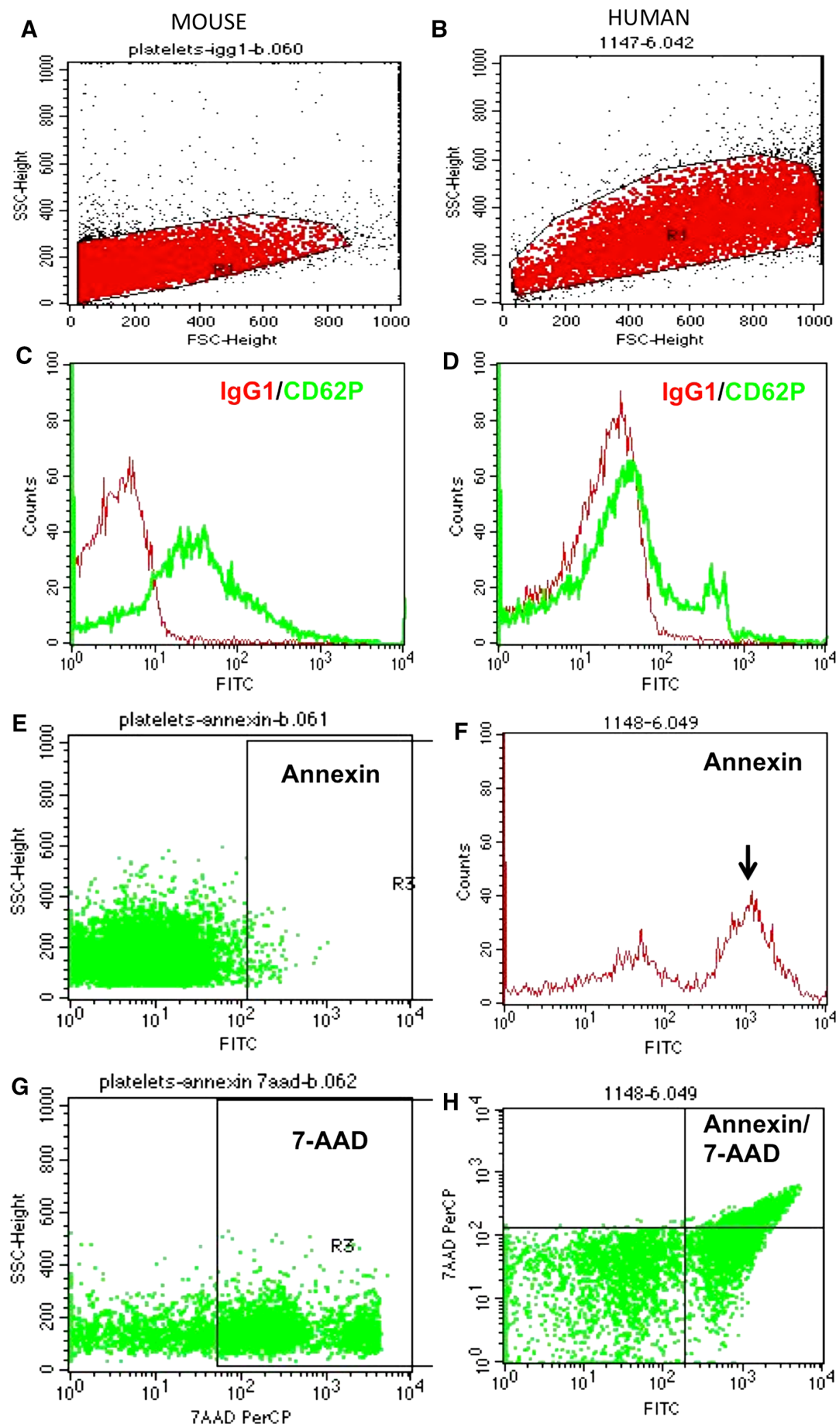
samples (Fig. 2; Table 4). However, the total platelet APP levels as measured by ELISA were significantly increased (Table 4). Using a novel IBL assay kit, significantly decreased $(\times 1.8)$ secreted APP $\beta$ in AD patients was found (Table 4). Although the measured levels were lower as compared to a previous used Covance ELISA system, the ratio of this decrease $(\times 1.5)$ remained similar (Table 4). Finally, a significant decrease in platelet EGF levels was found with a tendency towards increased EGF release (Table 4).

\section{Discussion}

Platelets modulate multiple cellular processes including angiogenesis and inflammation (Gawaz et al. 2005; Patzelt and Langer 2012) and are involved in a variety of pathologic conditions where they actively aggravate vascular changes as e.g. artherosclerotic events (Gawaz et al. 2005). Since it is known that ADpathology is accompanied by both inflammatory and vascular damaging processes, it seems likely that

Table 1 Hypercholesterolemia mouse model

\begin{tabular}{|c|c|c|c|}
\hline Months & sAPP $\beta$ & APP $110 \mathrm{kDa}$ & Serotonin \\
\hline \multicolumn{4}{|l|}{7} \\
\hline WT & $3780 \pm 330(5)-$ & $99 \pm 8(5)-$ & $59 \pm 11(5)-$ \\
\hline WT Chol & $3600 \pm 330(5) \mathrm{ns}$ & $80 \pm 8(5) \mathrm{ns}$ & $62 \pm 11(4) \mathrm{ns}$ \\
\hline \multicolumn{4}{|l|}{14} \\
\hline WT & $3809 \pm 332(5)$ & $146 \pm 16(5)-$ & $70 \pm 8(5)-$ \\
\hline WT Chol & $2097 \pm 909$ (4) ns & $180 \pm 29(5) \mathrm{ns}$ & $58 \pm 15(5) \mathrm{ns}$ \\
\hline \multicolumn{4}{|l|}{20} \\
\hline WT & $2077 \pm 464$ & $76 \pm 18(6)$ & $640 \pm 127(5)-$ \\
\hline WT Chol & $868 \pm 396(4) p=0.09$ & $105 \pm 33(5) \mathrm{ns}$ & $529 \pm 163(5) \mathrm{ns}$ \\
\hline
\end{tabular}

Wildtype mice (WT) were fed with or without $5 \%$ cholesterol (Chol). At the age of 7, 14 or 20 months platelets from WT or WTcholesterol animals were isolated and processed for secreted amyloid precursor protein beta (sAPP $\beta$ ) release, APP and serotonin. Values are given as mean $\pm \mathrm{SEM} \mathrm{pg} / \mathrm{ml} \times 25 \mu \mathrm{g} \times 150 \mathrm{~min}$ for sAPP $\beta$, optical density (OD) for APP and $\mathrm{ng} / \mathrm{mg} \mathrm{protein}$ for serotonin. Values in parenthesis give the number of animals. Statistical analysis was performed by One Way ANOVA with a subsequent Fisher-LSD posthoc test

ns not significant

Table 2 Triple transgenic (3xTg) Alzheimer's disease mouse model

\begin{tabular}{|c|c|c|c|}
\hline Months & sAPP $\beta$ & APP $110 \mathrm{kDa}$ & Serotonin \\
\hline \multicolumn{4}{|l|}{7} \\
\hline WT & $3780 \pm 330(5)-$ & $99 \pm 8(5)-$ & $59 \pm 11(5)-$ \\
\hline TG & $2360 \pm 740(5)^{*}$ & $52 \pm 16(5)^{*}$ & $20 \pm 2(5)^{* *}$ \\
\hline \multicolumn{4}{|l|}{14} \\
\hline WT & $3809 \pm 332(5)$ & $146 \pm 16(5)-$ & $70 \pm 8(5)-$ \\
\hline TG & $1899 \pm 552(5)^{*}$ & $49 \pm 21(5)^{* *}$ & $332 \pm 165(4)^{*}$ \\
\hline \multicolumn{4}{|l|}{20} \\
\hline WT & $2077 \pm 464$ & $76 \pm 18(6)$ & $640 \pm 127(5)-$ \\
\hline TG & $580 \pm 325(4)^{*}$ & $55 \pm 19(5) \mathrm{ns}$ & $365 \pm 123(5) \mathrm{ns}$ \\
\hline
\end{tabular}

At the age of 7, 14 or 20 months platelets from wildtype (WT) or 3xTg mice were isolated and processed for secreted amyloid precursor protein beta $(\mathrm{sAPP} \beta)$ release, APP and serotonin. Values are given as mean $\pm \mathrm{SEM} \mathrm{pg/ml} \times 25 \mu \mathrm{g} \times 150 \mathrm{~min}$ for sAPP $\beta$, optical density (OD) for APP and ng/mg protein for serotonin. Values in parenthesis give the number of animals. Statistical analysis was performed by One Way ANOVA with a subsequent Fisher-LSD posthoc test $(* \mathrm{p}<0.05 ; * * \mathrm{p}<0.01)$

$n s$ not significant 
Table 3 APP_SweDI Alzheimer's disease mouse model

\begin{tabular}{|c|c|c|c|c|}
\hline & \multicolumn{2}{|l|}{6 months } & \multicolumn{2}{|l|}{12 months } \\
\hline & WT & TG & WT & TG \\
\hline Cell population $(\%)$ & $66 \pm 14(4)$ & $87 \pm 2(6) \mathrm{ns}$ & $77 \pm 2(6)$ & $83 \pm 2(6) \mathrm{ns}$ \\
\hline CD620P (\%) & $39 \pm 12(4)$ & $42 \pm 11(6) \mathrm{ns}$ & $53 \pm 5(6)$ & $76 \pm 3(6)^{* *}$ \\
\hline Annexin V (\%) & $0.5 \pm 0.25(4)$ & $18 \pm 5(6)^{*}$ & $8.4 \pm 1.8(6)$ & $32 \pm 8(6)^{*}$ \\
\hline Annexin/7-AAD (\%) & $0.09 \pm 0.02$ & $2.7 \pm 0.7(6)^{*}$ & $2.4 \pm 0.6(6)$ & $12 \pm 4(6)^{*}$ \\
\hline APP WB 110 kDa (OD) & $134 \pm 47(7)$ & $129 \pm 30(7) \mathrm{ns}$ & $183 \pm 18(6)$ & $140 \pm 21(6) \mathrm{ns}$ \\
\hline APP (ng/mg protein) & $2.1 \pm 0.8(6)$ & $1.4 \pm 0.3(6) \mathrm{ns}$ & $9.1 \pm 3.1(5)$ & $12.8 \pm 6.7(6) \mathrm{ns}$ \\
\hline $\mathrm{sAPP} \beta(\mathrm{pg} / \mathrm{ml} \times 25 \mu \mathrm{g} \times 150 \mathrm{~min})$ & $1399 \pm 254(4)$ & $755 \pm 88(6)^{*}$ & $606 \pm 144(6)$ & $403 \pm 144(6) n s$ \\
\hline Serotonin (ng/mg protein) & $177 \pm 78(5)$ & $223 \pm 89(6) \mathrm{ns}$ & $291 \pm 99(6)$ & $397 \pm 96(6) \mathrm{ns}$ \\
\hline
\end{tabular}

At the age of 6 or 12 months platelets from wildtype (WT) or APP_SweDI (TG) mice were isolated and processed for FACS analysis, secreted amyloid precursor protein beta (SAPP $\beta$ ) release, APP (Western blot and ELISA) and serotonin. Values are given as mean \pm SEM; values in parenthesis give the number of animals. Statistical analysis was performed by One Way ANOVA with a subsequent Fisher-LSD posthoc test $(* \mathrm{p}<0.05$; ** $\mathrm{p}<0.01)$

$n s$ not significant, $O D$ optical density, $W B$ Western blot

platelets actively contribute to the progression of AD. Moreover, besides neurotransmitters, platelets contain proteins such as APP and produce beta-amyloid and secretases, making them an interesting target to study peripheral changes in $\mathrm{AD}$ as they may be useful biomarkers of the disease (Rainesalo et al. 2005; Chen et al. 1995; Li et al. 1999; Evin et al. 2003). In the present study we assessed platelet APP, sAPP $\beta$ and serotonin in three different mouse models and human patients with $\mathrm{AD}$; additionally, we evaluated platelet EGF levels in our human cohort, in order to evaluate whether these components are altered in $\mathrm{AD}$ and whether platelets are useful as peripheral biomarkers in $\mathrm{AD}$.

\section{Platelet population, CD62P and apoptosis}

Activated platelets undergo a rapid shape change and redistribute several proteins from their granules to their surface. In order to trigger the acquisition of activated platelets with the flow cytometer, surfacebound P-selectin was identified with a FITC-conjugated monoclonal antibody CD62P, a platelet-specific antigen. A negative control (IgG1) was incorporated in the protocol and the obtained values substracted from the CD62P positive events. CD62P is located on the inner membrane of $\alpha$-granules and released on the outside upon activation where it acts as a receptor and is thus a platelet activation/degranulation marker. Regarding platelet activation as quantified by CD62P,

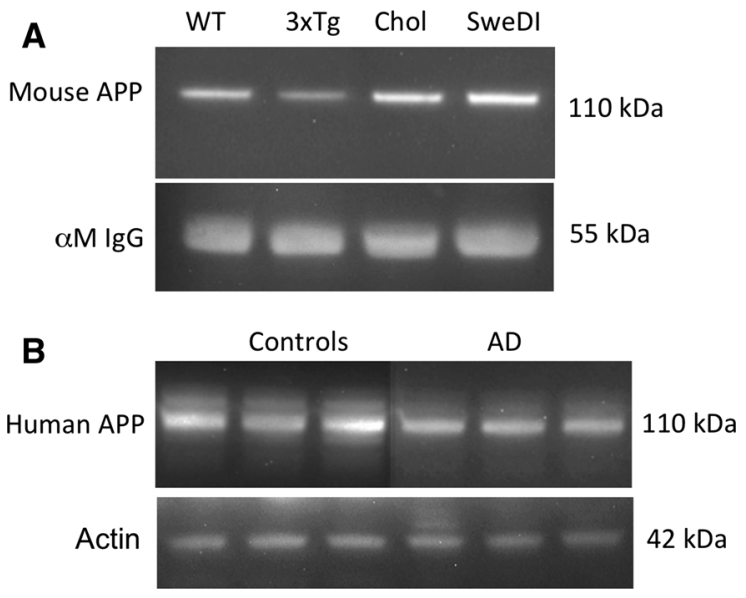

Fig. 2 Western blot analysis of amyloid precursor protein (APP) immunoreactivity in mouse (a) or human (b) platelets. In mice, one single APP band was seen at approx. $110 \mathrm{kDa}$ in wildtype (WT), triple transgenic (3xTg), cholesterol (Chol) or APP_SweDI (SweDI) mice. Loading control was performed using anti-mouse $\mathrm{IgG}$ showing a band at $55 \mathrm{kDa}(\mathbf{a})$. In humans, 2 bands were visible one larger at approximately $130 \mathrm{kDa}$ and a smaller at approximately 110/106 kDa (b). The larger $130 \mathrm{kDa}$ band declined in Alzheimer's disease patients (AD) compared to controls (b). Actin at $42 \mathrm{kDa}$ served as a loading control

contradicting results have been published: an elevated degree of platelet activation (Sevush et al. 1998), as well as no difference of membrane-attached P-selectin without agonist stimulation in $\mathrm{AD}$ was reported (Järemo et al. 2013). Also, increased P-selectin expression at baseline was found to significantly associate with faster cognitive decline (Stellos et al. 
Table 4 Human platelets

\begin{tabular}{llc}
\hline & Controls & AD \\
\hline Age (years) & $77 \pm 1(30)$ & $80 \pm 1(43)^{*}$ \\
Sex $(\mathrm{m} / \mathrm{f})$ & $10 / 20$ & $18 / 25 \mathrm{~ns}$ \\
MMSE & $29 \pm 0.3(30)$ & $18 \pm 1(43)^{* * *}$ \\
Cell population $(\%)$ & $50 \pm 2(30)$ & $56 \pm 3(43) \mathrm{ns}$ \\
CD62P $(\%)$ & $30 \pm 3(30)$ & $26 \pm 3(43) \mathrm{ns}$ \\
Annexin $(\%)$ & $29 \pm 3(30)$ & $33 \pm 4(43) \mathrm{ns}$ \\
Annexin/7ADD (\%) & $15 \pm 2(30)$ & $18 \pm 2(43) \mathrm{ns}$ \\
APP $130 \mathrm{kDa}(\mathrm{OD})^{\mathrm{a}}$ & $75 \pm 10(15)$ & $38 \pm 7(25)^{*}$ \\
APP $(110 / 106 \mathrm{kDa})(\mathrm{OD})^{\mathrm{a}}$ & $71 \pm 9(15)$ & $42 \pm 8(25) \mathrm{p}=0.08$ \\
APP $(\mathrm{ng} / \mathrm{mg} \mathrm{protein})$ & $2.6 \pm 0.3(30)$ & $3.3 \pm 0.2(43)^{*}$ \\
sAPP $\beta(\mathrm{pg} / \mathrm{ml} \times 25 \mu \mathrm{g} \times 150 \mathrm{~min})^{\mathrm{c}}$ & $519 \pm 50(33)$ & $1548 \pm 211(68)^{* * *}$ \\
sAPP $(\mathrm{pg} / \mathrm{ml} \times 25 \mu \mathrm{g} \times 150 \mathrm{~min})$ & $402 \pm 102(26)$ & $924 \pm 174(41)^{*}$ \\
Serotonin $(\mathrm{ng} / \mathrm{mg} \mathrm{protein})^{\mathrm{b}}$ & $565 \pm 79(11)$ & $529 \pm 88(22) \mathrm{ns}$ \\
Serotonin $(\mathrm{ng} / \mathrm{ml} \times \mathrm{mg} \times \mathrm{h})$ & $22 \pm 7(30)$ & $16 \pm 5(39) \mathrm{ns}$ \\
EGF $(\mathrm{pg} / \mathrm{mg} \mathrm{protein})$ & $365 \pm 56(25)$ & $170 \pm 66(36)^{*}$ \\
EGF $(\mathrm{pg} / \mathrm{ml} \times \mathrm{mg} \times \mathrm{h})$ & $66 \pm 7(25)$ & $87 \pm 9(36) \mathrm{p}=0.09$ \\
\hline
\end{tabular}

Platelets were isolated from healthy controls or Alzheimer's disease patients (AD) and processed for FACS analysis, secreted amyloid precursor protein beta (sAPP $\beta$ ) release, APP (Western Blot and ELISA), serotonin or EGF. Values are given as mean \pm SEM; values in parenthesis give the number of patients/controls. Statistical analysis was performed by Student's $t$ test $(* \mathrm{p}<0.05 ; * * * \mathrm{p}<0.001)$

$n s$ not significant, $O D$ optical density, MMSE, mini mental state examination

a Taken from Ehrlich et al. (2013) Platelets 24:26-36

b Taken from Hochstrasser et al. (2012b) Curr. Alzheimer Res. 9:982-989

c Taken from Marksteiner and Humpel (2013) Curr. Neurovasc. Res. 10:297-303 using a Covance ELISA

2010). In the present study we did not find significantly increased membrane-attached $\mathrm{P}$-selectin expression in human patients with AD and young APP_SweDI mice. However, we found a significant increase in CD62P binding in 12 month old APP_SweDI mice. This was accompanied by enhanced cell death as visualized with 7-aminoactinomycin D and significantly higher apoptoptis as seen with Annexin V. This suggests that platelets, besides increased activation, are also more sensitive to cell death in the AD mouse model. In contrast, human patients did not show altered platelet populations compared to healthy controls suggesting that mouse platelets are more vulnerable or that the $\mathrm{AD}$ mice do not fully display the human $\mathrm{AD}$ pathology.

\section{Serotonin}

Once released, platelet-derived serotonin modulates platelet aggregation at sites of vascular injury. As it has been demonstrated that activated platelets aggregate at sites of vascular $\mathrm{A} \beta$ promoting CAA by inducing platelet thrombus formation (Roher et al. 2009; Gowert et al. 2014), it is tempting to assume serotonin alterations in AD.

In the present study we observed significantly reduced platelet serotonin concentration in $3 \times \mathrm{Tg}$ mice at early stage. This can be due to both, enhanced platelet activity or decreased serotonin uptake in these transgenic mice. However, we did not see any alterations of serotonin concentrations in dietary hypercholesterolemia mouse models, APP_SweDI animals and human patients with AD. Thus, while some studies report reduced platelet serotonin content in hypercholesterolemia subjects and animal models (Smith and Betteridge 1997; Ogawa et al. 2000), we cannot report similar findings in our hypercholesterolemia mouse population.

Previous studies including ours failed to demonstrate altered serotonin processing in $\mathrm{AD}$ (Tukiainen 
et al. 1981; Andersson et al. 1991; Hochstrasser et al. 2012b), while a number of studies reported impaired uptake of platelet serotonin (Koren et al. 1993; Inestrosa et al. 1993) and significantly lower platelet serotonin concentration (Prokšelj et al. 2014; Mimica et al. 2008; Muck-Seler et al. 2009). These findings stand in contrast to other studies, postulating increased serotonin concentration (Kumar et al. 1995, Milovanovic et al. 2014). The discrepancy of these results may arise from different AD stages, as well as from diurnal and seasonal variations of serotonin (MuckSeler et al. 2009; Meyerson et al. 1989). We conclude that platelet serotonin levels fluctuate and have a high variability, and are therefore not suited as a reliable biomarker for $\mathrm{AD}$.

\section{Amyloid-precursor protein in platelets}

Platelets are an important peripheral source of APP, and three major isoforms (770, 751 and 695) are inserted in the membrane of resting platelets (Gardella et al. 1990; Bush et al. 1990; Di Luca et al. 2000). While APP695 lacks the KPI and OX-2 domains and is mainly expressed in neuronal cells, platelets preferably express the two KPI containing APP isoforms 770 and 751 (Tanzi et al. 1988; Golde et al. 1990; Mönning et al. 1992; Li et al. 1994). Additionally, platelets are also equipped with $\alpha$-, $\beta$-, and $\gamma$-secretases, thus being able to generate different $A \beta$ fragments (Colciaghi et al. 2004). Up to date, the physiological role of APP and its metabolites in platelets is not fully understood.

In several studies including ours, platelet APP ratio between the larger and lower isoforms of AD patients is significantly lower compared to healthy control subjects and correlate with disease severity (Di Luca et al. 1996, 1998, 2000; Borroni et al. 2004; Padovani et al. 2001; Baskin et al. 2000; Rosenberg et al. 1997; Zainaghi et al. 2012; Ehrlich et al. 2013). However, APP has not yet been established as a diagnostic biomarker for early AD (Zainaghi et al. 2012; Srisawat et al. 2013) because of its low diagnostic accuracy and methodological problems. In the present study, we confirm that platelet APP ratio is decreased, but we included in addition to Western Blot a quantitative analysis of the present cohort where we found the opposite trend. Moreover, we show for the first time that APP $110 \mathrm{kDa}$ isoform is reduced in the triple transgenic AD mouse model. This suggests that the 3xTg AD mouse model shares some similarities with the human $\mathrm{AD}$ pathology and indeed this model displays plaques as well as Tau pathology. Accordingly, the APP $110 \mathrm{kDa}$ isoform was unchanged in the hypercholesterolemia and APP_SweDI mouse models. In contrast to the findings that APP isoforms are decreased, our present study shows that the quantitative ELISA analysis of total APP reveals rather an increase of APP in human samples. While this seems to be a mismatch, it is likely that the ELISA system recognizes several forms of APP including secreted APP forms. Thus, the Western Blot is a more accurate method to differentiate between the APP isoforms. The development of an ELISA system highly specific for the $130 \mathrm{kDa}$ isoform may be of potential interest to increase reproducibility and sensitivity.

\section{Secreted APP $\beta$}

Secreted APP $\beta$ is released as an extracellular cleavage product after the first step within the amyloidogenic processing of APP. While the function of sAPP $\beta$ is not entirely clear, it has been proposed that secreted APP has neuroprotective and synapse promoting activities in the brain (Bandyopadhyay et al. 2007). Both, sAPP $\beta$ and SAPP $\alpha$ were moreover associated with decreased cell adhesion and increased axon elongation in vitro (Chasseigneaux et al. 2011). Our group has recently investigated both platelet sAPP $\beta$ and sAPP $\alpha$ levels, finding that SAPP $\beta$ but not sAPP $\alpha$ is markedly increased in MCI and AD patients (Marksteiner and Humpel 2013). In the present study we confirm a significantly increased sAPP $\beta$ release in AD patients. However, the formerly used Covance ELISA resulted in slightly higher levels of sAPP $\beta$ compared to the IBL ELISA used in this study. The observed increase of SAPP $\beta$ release is an indicator for enhanced APP cleavage in platelets of patients with $\mathrm{AD}$. In contrast to the increase of $\mathrm{APP} \beta$ release in AD patients, we found significantly decreased sAPP $\beta$ release in two transgenic mouse models $(3 \times \mathrm{Tg}$ and APP_SweDI) and additionally a trend towards reduced sAPP $\beta$ release in old (20 months) hypercholesterolemia mice. This controversy may be again due to the different pathological framework of mouse models and human patients. Altogether, while finding an opposed trend in mouse and humans, we were able to replicate our previous findings in human patients with a different ELISA assay. Thus, platelet sAPP $\beta$ release may represent therefore an interesting target worth further investigation. 
Epidermal growth factor in platelets

Growth factors play an important role in proliferation, differentiation and growth of numerous cell types. Platelets contain several growth factors, amongst others EGF, vascular endothelial growth factor or platelet-derived growth factor. Along with other proteins, EGF was found to be increased in plasma of patients with AD (Marksteiner et al. 2011; Björkqvist et al. 2012). As previously reported by our group, platelet EGF was significantly reduced in patients with AD (Hochstrasser et al. 2012b). In the present study we confirm that platelet EGF is reduced in AD patients. This reduction as seen in our studies stands in concordance with a described increase of plasma EGF levels, possibly caused by a continuous release of EGF by platelets under AD-conditions.

\section{Comparison mouse and human platelets}

This study shows that platelets undergo distinct changes in mouse models of $\mathrm{AD}$ and patients with AD compared to either wild type animals or cognitively healthy subjects. The results for AD mouse models are consistent for a decrease in APP $\beta$ secretion, which was found in both transgenic animal models. However, this alteration was inversely pronounced in human samples, where we observed a significant increase in secreted APP $\beta$ in patients with AD. The reduction of the optical density of APP $(130 \mathrm{kDa})$ in humans is likewise observed in the $110 \mathrm{kDa}$ isoform of $3 \mathrm{xTg}$ animals. An inconsistency was observed for serotonin levels and serotonin release with significant changes only in the triple transgenic model. A decrease in platelet EGF levels in human patients with $\mathrm{AD}$ confirms our previous findings. The overall results indicate that changes in $\mathrm{AD}$ are not limited to the central nervous system, but co-occur in peripheral blood cells such as platelets. More specifically, platelet EGF levels are altered in patients with $\mathrm{AD}$ and platelet APP expression and secretion is altered in $\mathrm{AD}$ patients with supporting evidence from AD mouse models. Both proteins, APP and EGF are worth further investigation as they may be useful peripheral biomarkers for AD. Hypercholesterolemia did not significantly trigger platelet changes in $\mathrm{AD}$ mouse models, supporting the hypothesis that the observed changes are $\mathrm{AD}$-specific, while a cholesterol diet alone does not alter platelet serotonin levels, APP expression or the secretion of APP $\beta$.

However, there are noticeable differences among the three mouse models and human patients with AD. The differences among the models and $\mathrm{AD}$ patients may reflect pathophysiological and neuropathological differences. Although we assessed platelets of highly valid transgenic animal models of $A D$ and hypercholesterolemia mice with comparable cognitive deficits, none of the currently available models recapitulates all pathological conditions of the human $\mathrm{AD}$ brain and they appear limited in mirroring sensitive peripheral changes as seen in the present study. Moreover, while mice represent an excellent model for studying platelet biology in vivo because murine platelets share properties with human platelets, they differ per se in some ultrastructural characteristics. We also found that platelets of a transgenic AD mouse population are generally more susceptible for apoptosis and necrosis compared to human platelets. While the significant tendency of reduced APP (130 kDa) as seen by Western blot in human patients with $\mathrm{AD}$ was supported by findings in our $3 \times$ Tg group $(110 \mathrm{kDa})$, the secretion of APP $\beta$ in transgenic animals is reversely pronounced as compared to humans. The discrepancy found in the secretion of APP $\beta$ by platelets demonstrates that murine peripheral APP is diversely processed in response to pathological conditions that are only of limited dimension compared to those seen in humans. Since APP secretion is closely linked to platelet activation, the observed difference may possibly be due to altered platelet reactivity in mouse models as seen by enhanced CD62P expression and cell death. Because platelet APP expression and processing seem overall affected in early and late $\mathrm{AD}$, this protein represents a highly interesting target worth further investigation within the search for peripheral biomarkers in human subjects. Likewise, the reduction of platelet EGF levels may be a promising marker for $\mathrm{AD}$-related changes and is in need of further evaluation.

Limitations of the study including methodological problems

(1) The cross-sectional design of this experiment precludes the long-term and time-dependent variation of the different platelet components. The biological 
effects of all measured biomarkers may vary with different stages of diseases and at different points of time. (2) Due to low sample volumes (1 ml EDTA blood from mice), EGF and FACS analysis could not be performed in the mouse models compared to humans (10 ml EDTA blood). (3) The number of human participants included in this study is relatively low. (4) In this study, only AD patients were included. Further studies are needed to understand, whether the observed alterations are AD-specific in terms of their ability to distinguish AD from clinically similar dementia forms. (5) Platelets are sensitive cells and require careful handling during preparation. After decades of study, there is still a general need to establish concurrent methods for the different processing steps of platelets because the wide variation of reported protocols for platelet preparation leads to different biological responses and incomparable data. Several variables (such as e.g. anticoagulants in collection tubes, time of processing, etc.) in the platelet preparation process need to be standardized to minimize artificial stimulation during blood collection and sample handling.

\section{Conclusion}

Biomarkers may have an immense scientific and clinical value through the whole progression of a disease. Our data support the hypothesis that platelets are dysfunctional in $\mathrm{AD}$ and $\mathrm{AD}$-like conditions, however, to date no AD-specific platelet biomarker has been clinically established. The inconsistencies of intra- and inter-person variability may account for this problem. We further show that transgenic mice do not fully display the human AD pathology also in respect of platelet alterations. Altogether, we believe that platelet biomarkers may become very useful in diagnosing early and late $\mathrm{AD}$.

Acknowledgments This study has been supported by the Austrian Science Funds (P24734-B24) and by the Österreichische Nationalbank Jubiläumsfonds (Nr. 15887). We thank Ursula Kirzenberger-Winkler and Karin Albrecht for their help with human blood processing and Western Blot analysis. We thank Nina Daschil for help with animal care and genotyping. We thank Monika Greil for help with blood processing.

Conflict of interest The authors declare that they have no conflict of interest.
Open Access This article is distributed under the terms of the Creative Commons Attribution 4.0 International License (http:// creativecommons.org/licenses/by/4.0/), which permits unrestricted use, distribution, and reproduction in any medium, provided you give appropriate credit to the original author(s) and the source, provide a link to the Creative Commons license, and indicate if changes were made.

\section{References}

Adolfsson R, Gottfries CG, Oreland L, Wiberg A, Winblad B (1980) Increased activity of brain and platelet monoamine oxidase in dementia of Alzheimer type. Life Sci 27(12):1029-1034

Andersson A, Adolfsson R, Eriksson K, Marcusson J (1991) Platelet $[3 \mathrm{H}]$ paroxetine binding to 5 -HT uptake sites in Alzheimer's disease. Neurobiol Aging 12(5):531-534

Arora RC, Emery OB, Meltzer HY (1991) Serotonin uptake in the blood platelets of Alzheimer's disease patients. Neurology 41(8):1307-1309

Bandyopadhyay S, Goldstein LE, Lahiri DK, Rogers JT (2007) Role of the APP non-amyloidogenic signaling pathway and targeting alpha-secretase as an alternative drug target for treatment of Alzheimer's disease. Curr Med Chem 14(27):2848-2864

Baskin F, Rosenberg RN, Iyer L, Hynan L, Cullum CM (2000) Platelet APP isoform ratios correlate with declining cognition in AD. Neurology 54(10):1907-1909

Björkqvist M, Ohlsson M, Minthon L, Hansson O (2012) Evaluation of a previously suggested plasma biomarker panel to identify Alzheimer's disease. PLoS One 7(1):e29868

Blennow K (2005) CSF biomarkers for Alzheimer's disease: use in early diagnosis and evaluation of drug treatment. Expert Rev Mol Diagn 5(5):661-672

Blennow K, Hampel H, Weiner M, Zetterberg H (2010) Cerebrospinal fluid and plasma biomarkers in Alzheimer disease. Nat Rev Neurol 6(3):131-144

Borroni B, Colciaghi F, Archetti S, Marcello E, Caimi L, Di Luca M, Padovani A (2004) Predicting cognitive decline in Alzheimer disease. Role of platelet amyloid precursor protein. Alzheimer Dis Assoc Dis 18(1):32-34

Borroni B, Agosti C, Marcello E, Di Luca M, Padovani A (2010) Blood cell markers in Alzheimer disease: amyloid precursor protein form ratio in platelets. Exp Gerontol 45(1):53-56

Bradshaw EM, Chibnik LB, Keenan BT, Ottoboni L, Raj T, Tang A, Rosenkrantz LL, Imboywa S, Lee M, Von Korff A, Alzheimer Disease Neuroimaging Initiative, Morris MC, Evans DA, Johnson K, Sperling RA, Schneider JA, Bennett DA, De Jager PL (2013) CD33 Alzheimer's disease locus: altered monocyte function and amyloid biology. Nat Neurosci 16(7):848-850

Bush AI, Martins RN, Rumble B, Moir R, Fuller S, Milward E, Currie J, Ames D, Weidemann A, Fischer P et al (1990) The amyloid precursor protein of Alzheimer's disease is released by human platelets. J Biol Chem 265(26):15977-15983

Casoli T, Di Stefano G, Balietti M, Solazzi M, Giorgetti B, Fattoretti P (2010) Peripheral inflammatory biomarkers of Alzheimer's disease: the role of platelets. Biogerontology 11(5):627-633 
Chasseigneaux S, Dinc L, Rose C, Chabret C, Coulpier F, Topilko P, Mauger G, Allinquant B (2011) Secreted amyloid precursor protein $\beta$ and secreted amyloid precursor protein $\alpha$ induce axon outgrowth in vitro through Egr1 signaling pathway. PLoS One 6(1):e16301

Chen M, Inestrosa NC, Ross GS, Fernandez HL (1995) Platelets are the primary source of amyloid beta-peptide in human blood. Biochem Biophy Res Commun 213(1):96-103

Chiu MJ, Yang SY, Horng HE, Yang CC, Chen TF, Chieh JJ, Chen HH, Chen TC, Ho CS, Chang SF, Liu HC, Hong CY, Yang HC (2013) Combined plasma biomarkers for diagnosing mild cognition impairment and Alzheimer's disease. ACS Chem Neurosci 4(12):1530-1536

Colciaghi F, Marcello E, Borroni B, Zimmermann M, Caltagirone C, Cattabeni F, Padovani A, Di Luca M (2004) Platelet APP, ADAM 10 and BACE alterations in the early stages of Alzheimer disease. Neurology 62(3):498-501

Davis J, Xu F, Deane R, Romanov G, Previti ML, Zeigler K, Zlokovic BV, Van Nostrand WE (2004) Early-onset and robust cerebral microvascular accumulation of amyloid beta-protein in transgenic mice expressing low levels of a vasculotropic Dutch/Iowa mutant form of amyloid betaprotein precursor. J Biol Chem 279(19):20296-20306

Di Luca M, Pastorino L, Cattabeni F, Zanardi R, Scarone S, Racagni G, Smeraldi E, Perez J (1996) Abnormal pattern of platelet APP isoforms in Alzheimer disease and down syndrome. Arch Neurol 53(11):1162-1166

Di Luca M, Pastorino L, Bianchetti A, Perez J, Vignolo LA, Lenzi GL, Trabucchi M, Cattabeni F, Padovani A (1998) Differential level of platelet amyloid beta precursor protein isoforms: an early marker for Alzheimer disease. Arch Neurol 55(9):1195-1200

Di Luca M, Colciaghi F, Pastorino L, Borroni B, Padovani A, Cattabeni F (2000) Platelets as a peripheral district where to study pathogenetic mechanisms of alzheimer disease: the case of amyloid precursor protein. Eur J Pharmacol 405(1-3):277-283

Dubois B, Feldman HH, Jacova C, Dekosky ST, BarbergerGateau P, Cummings J, Delacourte A, Galasko D, Gauthier S, Jicha G, Meguro K, O’brien J, Pasquier F, Robert P, Rossor M, Salloway S, Stern Y, Visser PJ, Scheltens P (2007) Research criteria for the diagnosis of Alzheimer's disease: revising the NINCDS-ADRDA criteria. Lancet Neurol 6(8):734-746

Ehrlich D, Hochstrasser T, Humpel C (2013) Effects of oxidative stress on amyloid precursor protein processing in rat and human platelets. Platelets 24(1):26-36

El Haouari M, Rosado JA (2009) Platelet function in hypertension. Blood Cells Mol Dis 42(1):38-40

Evin G, Zhu A, Holsinger RM, Masters CL, Li QX (2003) Proteolytic processing of the Alzheimer's disease amyloid precursor protein in brain and platelets. J Neurosci Res 74(3):386-392

Gardella JE, Ghiso J, Gorgone GA, Marratta D, Kaplan AP, Frangione B, Gorevic PD (1990) Intact Alzheimer amyloid precursor protein (APP) is present in platelet membranes and is encoded by platelet mRNA. Biochem Biophys Res Commun 173(3):1292-1298

Gawaz M, Langer H, May AE (2005) Platelets in inflammation and atherogenesis. J Clin Investig 115(12):3378-3384
Golde TE, Estus S, Usiak M, Younkin LH, Younkin SG (1990) Expression of beta amyloid protein precursor mRNAs: recognition of a novel alternatively spliced form and quantitation in Alzheimer's disease using PCR. Neuron 4:253-267

Gowert NS, Donner L, Chatterjee M, Eisele YS, Towhid ST, Münzer P, Walker B, Ogorek I, Borst O, Grandoch M, Schaller M, Fischer JW, Gawaz M, Weggen S, Lang F, Jucker M, Elvers M (2014) Blood platelets in the progression of Alzheimer's disease. PLoS One 9(2):e90523

Hochstrasser T, Marksteiner J, Humpel C (2012a) Telomere length is age-dependent and reduced in monocytes of Alzheimer patients. Exp Gerontol 47(2):160-163

Hochstrasser T, Ehrlich D, Marksteiner J, Sperner-Unterweger B, Humpel C (2012b) Matrix metalloproteinase-2 and epidermal growth factor are decreased in platelets of Alzheimer patients. Curr Alzheimer Res 9(8):982-989

Hohsfield LA, Ehrlich D, Humpel C (2014) Intravenous infusion of nerve growth factor-secreting monocytes supports the survival of cholinergic neurons in the nucleus basalis of Meynert in hypercholesterolemia brown-Norway rats. J Neurosci Res 92(3):298-306

Hu WT, Holtzman DM, Fagan AM, Shaw LM, Perrin R, Arnold SE, Grossman M, Xiong C, Craig-Schapiro R, Clark CM, Pickering E, Kuhn M, Chen Y, Van Deerlin VM, McCluskey L, Elman L, Karlawish J, Chen-Plotkin A, Hurtig HI, Siderowf A, Swenson F, Lee VM, Morris JC, Trojanowski JQ, Soares H (2012) Alzheimer's disease neuroimaging initiative. Plasma multianalyte profiling in mild cognitive impairment and Alzheimer disease. Neurology 79(9):897-905

Hu N, Tan MS, Sun L, Jiang T, Wang YL, Tan L, Zhang W, Yu JT, Tan L (2014) Decreased expression of CD33 in peripheral mononuclear cells of Alzheimer's disease patients. Neurosci Lett 563:51-54

Humpel C (2011) Identifying and validating biomarkers for Alzheimer's disease. Trends Biotechnol 29(1):26-32

Inestrosa NC, Alarcón R, Arriagada J, Donoso A, Alvarez J (1993) Platelet of Alzheimer patients: increased counts and subnormal uptake and accumulation of $\left[{ }^{14} \mathrm{C}\right] 5$-hydroxytryptamine. Neurosci Lett 163(1):8-10

Järemo P, Milovanovic M, Buller C, Nilsson S, Winblad B (2013) P-selectin paradox and dementia of the Alzheimer type: circulating P-selectin is increased but platelet-bound $\mathrm{P}$-selectin after agonist provocation is compromised. Scand J Clin Lab Investig 73(2):170-174

Jarre A, Gowert NS, Donner L, Münzer P, Klier M, Borst O, Schaller M, Lang F, Korth C, Elvers M (2014) Pre-activated blood platelets and a pro-thrombotic phenotype in APP23 mice modeling Alzheimer's disease. Cell Signal 26(9):2040-2050

Kassner SS, Bonaterra GA, Kaiser E, Hildebrandt W, Metz J, Schröder J, Kinscherf R (2008) Novel systemic markers for patients with Alzheimer disease?-A pilot study. Curr Alzheimer Res 5(4):358-366

Kokjohn TA, Van Vickle GD, Maarouf CL, Kalback WM, Hunter JM, Daugs ID, Luehrs DC, Lopez J, Brune D, Sue LI, Beach TG, Castaño EM, Roher AE (2011) Chemical characterization of pro-inflammatory amyloid-beta peptides in human atherosclerotic lesions and platelets. Biochim Biophys Acta 1812(11):1508-1514 
Koren P, Diver-Haber A, Adunsky A, Rabinowitz M, Hershkowitz M (1993) Uptake of serotonin into platelets of senile dementia of the Alzheimer type patients. J Gerontol 48(3):B93-B96

Kumar AM, Sevush S, Kumar M, Ruiz J, Eisdorfer C (1995) Peripheral serotonin in Alzheimer's disease. Neuropsychobiology 32(1):9-12

Li QX, Berndt MC, Bush AI, Rumble B, Mackenzie I, Friedhuber A, Beyreuther K, Masters CL (1994) Membraneassociated forms of the beta A4 amyloid protein precursor of Alzheimer's disease in human platelet and brain: surface expression on the activated human platelet. Blood 84(1):133-142

Li QX, Fuller SJ, Beyreuther K, Masters CL (1999) The amyloid precursor protein of Alzheimer disease in human brain and blood. J Leukoc Biol 66(4):567-574

Marksteiner J, Humpel C (2013) Platelet-derived secreted amyloid-precursor protein- $\beta$ as a marker for diagnosing Alzheimer's disease. Curr Neurovasc Res 10(4):297-303

Marksteiner J, Kemmler G, Weiss EM, Knaus G, Ullrich C, Mechtcheriakov S, Oberbauer H, Auffinger S, Hinterhölzl J, Hinterhuber H, Humpel C (2011) Five out of 16 plasma signaling proteins are enhanced in plasma of patients with mild cognitive impairment and Alzheimer's disease. Neurobiol Aging 32(3):539-540

McKhann G, Drachman D, Folstein M, Katzman R, Price D, Stadlan EM (1984) Clinical diagnosis of Alzheimer's disease: report of the NINCDS-ADRDA Work Group under the auspices of Department of Health and Human Services Task Force on Alzheimer's Disease. Neurology 34(7):939-944

Meyerson LR, Strano R, Ocheret D (1989) Diurnal concordance of human platelet serotonin content and plasma alpha-1acid glycoprotein concentration. Pharmacol Biochem Behav 32(4):1043-1047

Milovanovic M, Eriksson K, Winblad B, Nilsson S, Lindahl TL, Post C, Järemo P (2014) Alzheimer and platelets: lowdensity platelet populations reveal increased serotonin content in Alzheimer type dementia. Clin Biochem 47(15):51-53

Mimica N, Mück-Seler D, Pivac N, Mustapić M, Dezeljin M, Stipcević T, Presecki P, Radonić E, Folnegović-Smalc V (2008) Platelet serotonin and monoamine oxidase in Alzheimer's disease with psychotic features. Coll Antropol 32(Suppl 1):119-122

Mönning U, König G, Banati RB, Mechler H, Czech C, Gehrmann J, Schreiter-Gasser U, Masters CL, Beyreuther K (1992) Alzheimer beta A4-amyloid protein precursor in immunocompetent cells. J Biol Chem 267:23950-23956

Muck-Seler D, Presecki P, Mimica N, Mustapic M, Pivac N, Babic A, Nedic G, Folnegovic-Smalc V (2009) Platelet serotonin concentration and monoamine oxidase type B activity in female patients in early, middle and late phase of Alzheimer's disease. Prog Neuropsychopharmacol Biol Psychiatry 33(7):1226-1231

Naert G, Rivest S (2013) A deficiency in CCR2+ monocytes: the hidden side of Alzheimer's disease. J Mol Cell Biol 5(5):284-293

Neumann K, Farías G, Slachevsky A, Perez P, Maccioni RB (2011) Human platelets tau: a potential peripheral marker for Alzheimer's disease. J Alzheimers Dis 25(1):103-109
Oddo S, Caccamo A, Shepherd JD, Murphy MP, Golde TE, Kayed R, Metherate R, Mattson MP, Akbari Y, LaFerla FM (2003) Triple-transgenic model of Alzheimer's disease with plaques and tangles: intracellular Abeta and synaptic dysfunction. Neuron 39(3):409-421

Ogawa T, Sugidachi A, Asai F, Koike H (2000) Reduced platelet serotonin content in rabbits with dietary hypercholesterolemia. Blood Coagul Fibrinolysis 11(4):313-319

Padovani A, Pastorino L, Borroni B, Colciaghi F, Rozzini L, Monastero R, Perez J, Pettenati C, Mussi M, Parrinello G, Cottini E, Lenzi GL, Trabucchi M, Cattabeni F, Di Luca M (2001) Amyloid precursor protein in platelets: a peripheral marker for the diagnosis of sporadic AD. Neurology 57(12):2243-2248

Patzelt J, Langer HF (2012) Platelets in angiogenesis. Curr Vasc Pharmacol 10(5):570-577

Prokšelj T, Jerin A, Muck-Seler D, Kogoj A (2014) Decreased platelet serotonin concentration in Alzheimer's disease with involuntary emotional expression disorder. Neurosci Lett 578:71-74

Rainesalo S, Keränen T, Saransaari P, Honkaniemi J (2005) GABA and glutamate transporters are expressed in human platelets. Mol Brain Res 141(2):161-165

Ray S, Britschgi M, Herbert C, Takeda-Uchimura Y, Boxer A, Blennow K, Friedman LF, Galasko DR, Jutel M, Karydas A, Kaye JA, Leszek J, Miller BL, Minthon L, Quinn JF, Rabinovici GD, Robinson WH, Sabbagh MN, So YT, Sparks DL, Tabaton M, Tinklenberg J, Yesavage JA, Tibshirani R, Wyss-Coray T (2007) Classification and prediction of clinical Alzheimer's diagnosis based on plasma signaling proteins. Nat Med 13(11):1359-1362

Roher AE, Esh CL, Kokjohn TA, Castaño EM, Van Vickle GD, Kalback WM, Patton RL, Luehrs DC, Daugs ID, Kuo YM, Emmerling MR, Soares H, Quinn JF, Kaye J, Connor DJ, Silverberg NB, Adler CH, Seward JD, Beach TG, Sabbagh MN (2009) Amyloid beta peptides in human plasma and tissues and their significance for Alzheimer's disease. Alzheimers Dement 5(1):18-29

Rosenberg RN, Baskin F, Fosmire JA, Risser R, Adams P, Svetlik D, Honig LS, Cullum CM, Weiner MF (1997) Altered amyloid protein processing in platelets of patients with Alzheimer disease. Arch Neurol 54(2):139-144

Sevush S, Jy W, Horstman LL, Mao WW, Kolodny L, Ahn YS (1998) Platelet activation in Alzheimer disease. Arch Neurol 55(4):530-536

Shad KF, Aghazadeh Y, Ahmad S, Kress B (2013) Peripheral markers of Alzheimer's disease: surveillance of white blood cells. Synapse 67(8):541-543

Skovronsky DM, Lee VM, Praticò D (2001) Amyloid precursor protein and amyloid beta peptide in human platelets. Role of cyclooxygenase and protein kinase C. J Biol Chem 276(20):17036-17043

Smith CC, Betteridge DJ (1997) Reduced platelet serotonin content and release in familial hypercholesterolaemia. Atherosclerosis 130(1-2):87-92

Song F, Poljak A, Smythe GA, Sachdev P (2009) Plasma biomarkers for mild cognitive impairment and Alzheimer's disease. Brain Res Rev 61(2):69-80

Sparks DL, Scheff SW, Hunsaker JC III, Liu H, Landers T, Gross DR (1994) Induction of Alzheimer-like beta- 
amyloid immunoreactivity in the brains of rabbits with dietary cholesterol. Exp Neurol 126(1):88-94

Srisawat C, Junnu S, Peerapittayamongkol C, Futrakul A, Soiampornkul R, Senanarong V, Praditsuwan R, Assantachai P, Neungton N (2013) The platelet amyloid precursor protein ratio as a diagnostic marker for Alzheimer's disease in Thai patients. J Clin Neurosci 20(5):644-648

Stellos K, Panagiota V, Kögel A, Leyhe T, Gawaz M, Laske C (2010) Predictive value of platelet activation for the rate of cognitive decline in Alzheimer's disease patients. J Cereb Blood Flow Metab 30(11):1817-1820

Tang K, Hynan LS, Baskin F, Rosenberg RN (2006) Platelet amyloid precursor protein processing: a bio-marker for Alzheimer's disease. J Neurol Sci 240(1-2):53-58

Tanzi RE, McClatchey AI, Lamperti ED, Villa-Komaroff L, Gusella JF, Neve RL (1988) Protease inhibitor domain encoded by an amyloid protein precursor mRNA associated with Alzheimer's disease. Nature 331(6156):528-530

Tapiola T, Alafuzoff I, Herukka SK, Parkkinen L, Hartikainen P, Soininen H, Pirttilä T (2009) Cerebrospinal fluid \{beta\}amyloid 42 and tau proteins as biomarkers of Alzheimertype pathologic changes in the brain. Arch Neurol 66(3):382-389
Trillo L, Das D, Hsieh W, Medina B, Moghadam S, Lin B, Dang V, Sanchez MM, De Miguel Z, Ashford JW, Salehi A (2013) Ascending monoaminergic systems alterations in Alzheimer's disease. Translating basic science into clinical care. Neurosci Biobehav Rev 37(8):1363-1379

Tukiainen E, Wikström J, Kilpeläinen H (1981) Uptake of 5-hydroxytryptamine by blood platelets in Huntington's chorea and Alzheimer type of presenile dementia. Med Biol 59(2):116-120

Ullrich C, Pirchl M, Humpel C (2010) Hypercholesterolemia in rats impairs the cholinergic system and leads to memory deficits. Mol Cell Neurosci 45(4):408-417

Zainaghi IA, Talib LL, Diniz BS, Gattaz WF, Forlenza OV (2012) Reduced platelet amyloid precursor protein ratio (APP ratio) predicts conversion from mild cognitive impairment to Alzheimer's disease. J Neural Transm 119(7):815-819

Zetterberg H, Blennow K, Hanse E (2010) Amyloid beta and APP as biomarkers for Alzheimer's disease. Exp Gerontol 45(1):23-29 